\title{
Finance Leasing and ARMA Forecasting: Evidence from Albania
}

\author{
Alban Korbi, and Llesh Lleshaj
}

\begin{abstract}
Ten financial institutions are offering finance leasing-loans in Albania. Even though finance leasing is a potential financing resource for small and medium enterprises in Albania (which are on average $95 \%$ of national enterprises), the value of finance leasing is one thousand times smaller than other forms of medium and long-term loans or real estate loans. Developing of finance leasing is a challenge for the progress of the financial sector, and untapped potential as well. Currently, the finance leasing portfolio is dominated by financing for personal vehicles and work-vehicles, therefore diversification of leasing products is an immediate need of consumers. This study analyzes the value of finance leasing in Albania with time series from 2008 to 2020 (with quarterly frequency). The methodology applied for data processing is the co-integration method of finance leasing and other forms of medium-term and long-term financing. Also, the ARMA method is used to forecast the value of finance leasing. We found out that there is no long-run relationship between finance leasing with medium and long-term loans. Therefore, econometric tests suggest optimal forecasting ARMA (1,1) modeling. The parameters of ARMA model are positive statistically significant with autocorrelation AR (1) and negative statistically significant with the moving average MA (1), and forecasting values have a short-run equilibrium with a wide interval.
\end{abstract}

Index Terms - finance leasing, leasing portfolio, leasing forecasting equilibrium.

\section{INTRODUCTION}

The determination of the finance leasing in Albania is in the accordance with the International Accounting Standards (IAS 17), so that "a finance lease if the lease transfers substantially all the risks and rewards incidental to ownership". According to IAS 17 the leases in the financial statements of lessees-finance leases are at the commencement of the lease term, lessees recognize finance leases as assets and liabilities in their statements of financial position at amounts equal to the fair value of the leased property or, if lower, the present value of the minimum lease payments, each determined at the inception of the lease.

Understanding finance leasing, firstly, we must understand its importance in the financing process. Finance leasing is the agreement cannot be cancelled. The length of this basic term depends on the economic life of the asset and is usually shorter than the expected life of the asset. This arrangement enables the lessee to use the asset after the expiry of the basic period, or alternatively the lessee may buy the asset at a negotiated price on the termination of the

Published on December 28, 2020.

Alban Korbi, University of Tirana, Albania.

(e-mail: albankorbi@ feut.edu.al)

Llesh Lleshaj, University of Tirana, Albania.

(corresponding e-mail: 1leshlleshaj@feut.edu.al) lease. Financial lease is commonly used in case of land and buildings and very expensive equipment. The lessor generally is able to recover his investment in the asset during the lease period. Under this arrangement, the lessor borrows funds from the lender and provides a part of the money to acquire the asset. The lessor services the debt out of lease rentals. Thus, there is third party (lender) in addition to the lessor and the lessee. The lender is usually a financial institution or a commercial bank. Currently, in Albania, there are ten financial institutions that operate in this sector by offering these main lease-products.

The businesses, especially the small and medium ones, have the possibility, through the financial leasing institutions, to ensure the financing sources but also modern technological lines, machineries, vehicles or services from consolidated producers or furnishers in the country and abroad, by enabling the increase of their products and services quality. This way become competitive in the internal and foreign markets. Some of the main advantages and disadvantages of finance leasing are:

\section{Advantages:}

Liquidity - the lessee can use the asset to earn without investing money in the asset.

Convenience - financing fixed assets with no mortgage.

Hidden liability - leasing helps the lessee to report a better debt-equity ratio.

No risk of obsolescence - the risk of the asset becoming obsolete due to technological advancements is borne by the lessor.

Cost saving - lease rentals are deductible from taxable income. Obligation in bankruptcy is under debt financing.

\section{Disadvantages:}

Nominated asset - the lessee gets only the right to use the asset (the asset may be taken back from the lessee).

Restrictions on the lessee - the lessee cannot make alterations or improvements in the asset without the prior approval of the lessor.

Obligation - the lessee has to pay lease rentals on a regular basis to the lessor.

This study analyzes the value of finance leasing in Albania over the time 2008-2020 (with time series with quarterly frequency). Using analyzes based on cointegration techniques of finance leasing and other forms of medium-term and long-term financing. Also, the ARMA method is used to forecast the value of finance leasing.

There are several main reasons that motivate this study to focus on finance leasing: Firstly, this financial source is a very good financing potential for small and medium businesses in Albania (on average $95 \%$ of national enterprises are small or medium businesses). Secondly, finance leasing in Albania is a new financial market, there is an immediate need for studies from both the financier and 
banker experts as well as in the academics. Still, the value of finance leasing is one thousand times smaller than other forms of medium and long-term loans or real estate loans. Therefore, this financial subsector needs to be promoted and developed. Thirdly, the development of the financial subsector (finance leasing is a part of it) progresses the growth of the financial sector and the economy in general.

\section{LITERATURE REVIEW}

Leasing involves the purchase of fixed assets by a "lender" known as a lessor. Leasing is a very common method of financing equipment, motor vehicles, and real estate in many countries by both banks and other institutions. The lessor purchases the fixed assets and then simultaneously enters a rental contract with the lessee (the "borrower") that specifies the payment schedule. The contract often contains an option whereby the lessee can purchase the assets at the end of the lease at a pre-specified price [4]. In the past, the main focus of finance leasing was on tax differences from the lessor and lessee positions [28]. Years later finance leasing is primarily financing based on the asset [6]. The owner of the asset will retain ownership of the asset during the whole period of the lease [5], and the lessee will have to pay agreed periodic rentals for using the leased asset based on the arrangements that were made on the contract [9].

Nowadays, leasing is a transaction technology because underwriting is substantially based on hard information about the value of the underlying asset, analogous to assetbased lending, factoring, and fixed-asset lending. Also, leasing can be used to provide financing to opaque firms because the underwriting decision is primarily based on the value of the asset being leased. It has also been shown that leasing can mitigate an adverse selection problem, either in the used equipment market by encouraging a higher quality of product sold "off-lease" (i.e., sold by lessors when the purchase option is not exercised) or in the new product market [8], [15], [18]. By leasing IT inputs, inputs that fall in price over time because of technological advance incumbent firms reduce the possibility that they will be stuck with outdated technology whereas potential entrants have lower-cost technology. Specifically, if the gain on the new technology translates to a bigger 'saving' on marginal costs than the added cost of leasing as opposed to buying, then leasing will increase the ability to deter entry [22].

Leasing is often considered as an alternative to mediumor long-term credit [12]. Also, leasing is an opportunity for financing and people, so leasing allows them who could not have been able to borrow from traditional bank lending systems due to the limitation in their credit histories to access the right to use capital equipment [4]. The limitations in the availability of credit forces the entrepreneurs to rely only on finances that are emanating from their savings or in other cases by borrowing from friends and. So, the major problems that small manufacturing companies face is the lack of finances or the access to credit facilities. This in turn affects the number of choices that a firm can have as regards financing as they do not have many alternatives that they can turn to [25]. In this point of view the primary advantage of leasing business equipment is that it allows entrepreneurs or individuals to acquire assets with minimal initial expenditures.

In this context, a major advantage of the finance leasing in Albania, in comparison to the banking loan, is lower cost, because lease is a financial contract does not require collaterals [20]. Consequently, leasing is considered by entrepreneurs as a financing source with more opportunity than the banking loan [30]. Businesses often having not enough assets to give collateral to the banks, limit the possibility of their financing through banking loans. There were made studies where it was concluded a positive relation of the financial limit's existence of the firms and the finance leasing [14]. On the other hand, finance leasing does not have a direct relationship with the business cycle, so this financing source is potentially usable in every period of development of a business.

\section{FinANCE LEASING IN AlbANiA}

Most of the portfolio of non-bank financial entities consists of lending and microcredit $(73.5 \%)$, followed by the portfolio of financial leasing entities $(25 \%)$ and the portfolio of factoring entities (1.5\%). The lending portfolio for these entities is only $5.7 \%$ of the banking system portfolio [3].

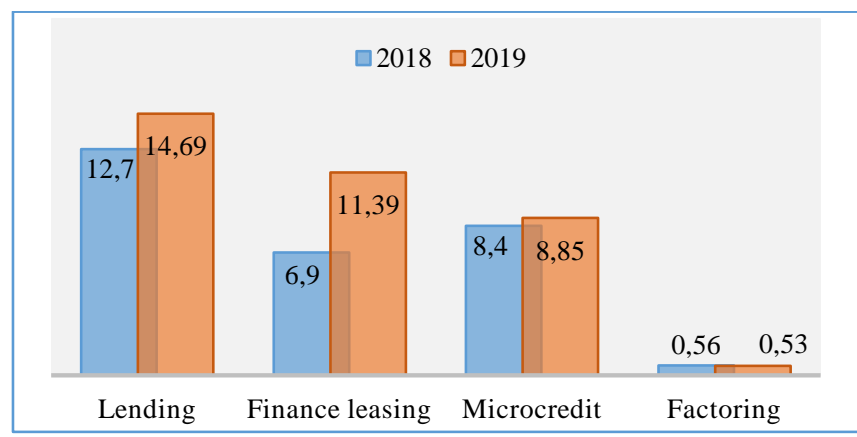

Fig. 1. Portfolio of non-bank financial institutions, in 2018 and 2019 (in billion ALL)

Currently, in the field of financing with leasing are ten non-bank financial institutions that are operating in the Albanian market. The earliest institutional establishment is in the years 2007/8, as it is seen this subsector is a new leasing financing market in Albania, so it cannot be the main source of medium-term financing for businesses. At the end of 2019, the activities of lending and finance leasing institutions continue to be business-oriented, about $71 \%$ and $82 \%$, respectively, while the factoring portfolio is carried out entirely for business purposes. Comparing 2019 with 2018 , there is an increase in lending to households rather than business (29\% vs. $20 \%$ ), which is realized due to microcredit activity.

Analyzing the performance of the finance leasing from 2008-2020 (with quarterly frequency), we have the following, Fig. 2. As shown by this figure, the trend of finance leasing after 2015 has marked an increase in the value of financing. This has happened for two reasons: firstly, before 2015 the leasing financing market was in the launch phase of these financial entities and their products. Secondly, after 2015 some of the leasing entities were absorbed by commercial banks. According to the stress test conducted by the Bank of Albania, it was concluded that the 
leasing market became more optimistic.

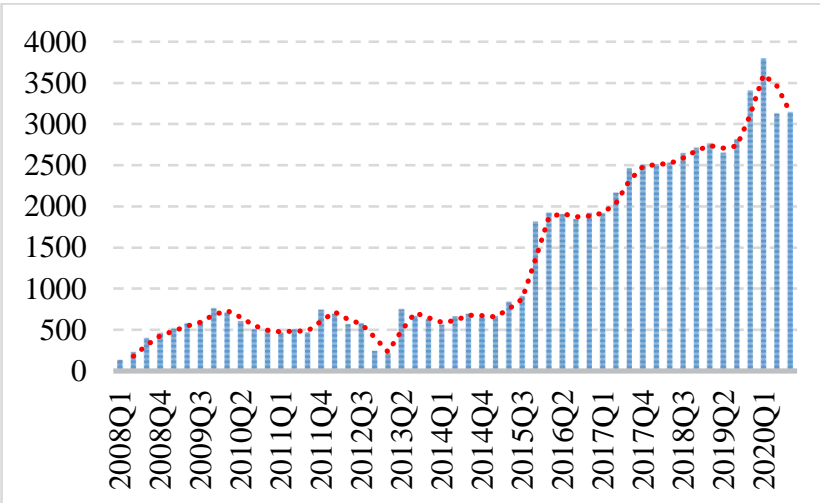

Fig. 2. Finance leasing in Albania (in million ALL), 2008Q1 - 2020Q3.

Analyzing the purpose of this financing, figure 3 , the finance leasing portfolio is dominated by financing for personal vehicles $(56.2 \%)$ and work-vehicles (28\%). Comparing it with December 2018, this portfolio marks an increase of about ALL 1.93 billion, due to "personal vehicles" [3].

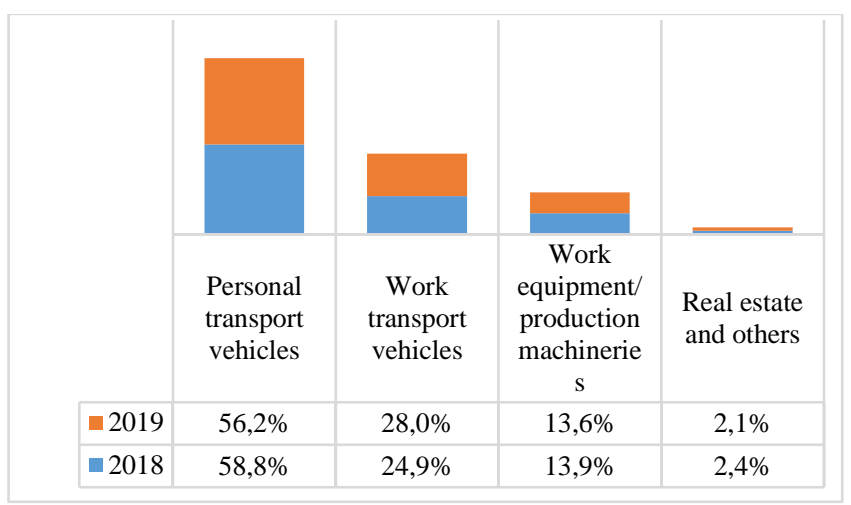

Fig. 3. Portfolio of finance leasing in Albania, 2018 and 2019.

Analyzing the time series data of long-term financing and medium-term financing for the period 2008 - 2020 (with quarterly frequency) we have found out the correlation matrix as in table 1 . We emphasize that according to the data 2008-2020 taken in the analysis, the value of finance leasing is on average one thousand times smaller than the value of other forms of financing in Albania.

TABLE I: CORRELATION MATRIX FOR MEDIUM- AND LONG-TERM LOANS

\begin{tabular}{ccccc}
\multicolumn{5}{c}{$(2008 \mathrm{Q} 1-2020 \mathrm{Q} 3)$} \\
\hline Correlation matrix & $\begin{array}{c}\text { Finance } \\
\text { leasing }\end{array}$ & $\begin{array}{c}\text { Long- } \\
\text { term loans }\end{array}$ & $\begin{array}{c}\text { Medium- } \\
\text { term loans }\end{array}$ & $\begin{array}{c}\text { Real estate } \\
\text { loans }\end{array}$ \\
\hline $\begin{array}{c}\text { Finance leasing } \\
\text { Long-term loans } \\
\text { Medium-term } \\
\text { loans }\end{array}$ & $\begin{array}{c}1.0000 \\
0.8004^{*}\end{array}$ & 1.0000 & & \\
Real estate loans & 0.2002 & $0.5880^{*}$ & 1.0000 & \\
\hline
\end{tabular}

Note: *) for statistical significance level of $\mathrm{p}<1 \%$. Source: authors' calculation in Eviews 11.

The analysis of the correlation coefficients given through the correlation matrix from Table 1 , shows us that there is a strong and statistically significant positive correlation between finance leasing and long-term financing (for individuals and businesses). While finance leasing and medium-term loans (for individuals and businesses) have a weak and statistically insignificant correlation. This phenomenon is explained by the finance leasing portfolio, as it is mentioned above, which is dominated by vehicles for family needs or transport by businesses, so finance leasing is not yet used by businesses in Albania as medium-term financing in production lines, machinery, etc. In addition, we can argue that the lack of use of finance leasing as a medium-term financing source makes businesses in Albania unable to diversify the cost of their capital (i.e., they lost potential diversification). Whereas the correlation of finance leasing with long-term loans exists for the effect of the accounting records in the national register of loans and loan accounts in the accounting balance sheets of companies.

\section{RESEARCH METHODOLOGY}

In this study are used the techniques and analysis of ARMA (Autoregressive and Moving Average Process) and co-integration, with some macro-financial variables. The data are taken from official statistics published in statistical reports and institutional studies. These data represent a 3month time series, for 2008-2020. The analysis will begin with finding significant statistical relationships of the unit root, co-integration, and ARMA estimate.

ADF Test of Unit Root: ADF Test of Unit Root. This test is the fundamental of testing the series and return to a stationary series. To realize this, we have used the Augmented Dickey-Fuller test (ADF). According to this test, we test whether a time series of data is influenced by its initial value, by the trend of time or by both simultaneously. The basic equation of ADF test linked with the constant and the trend (first order integral) is:

$$
\Delta X_{t}=\lambda_{0}+\lambda_{1} t+\lambda_{2} X_{t-1}+\sum_{i=1}^{p-1} \lambda_{i} \Delta X_{t-1}+\varepsilon_{t}
$$

There are 3 cases for the specification of $A R(p)$ model above: case 1: No constant term (no drift) and no linear trend in the model; case 2: Constant term (drift) but no linear trend; and case 3: constant term (drift) and linear trend. This equation shows a time series (variable in the study) in the form of the first difference $\Delta X_{t}=X_{t}-X_{t-1}$ in the period $t$, where $\lambda_{0}$ is the constant and $t$ is the trend, with the null hypothesis, H0: $\lambda_{2}=0$ (time series data is nonstationary).

Johansen test for co-integration: After addressing the issue of unit root, the co-integration test can be applied in order to establish the long run relationship among the variables. To identify this long-run relationship we will use the trace test for co integration and its maximum eigenvalue statistic [17], [19]. Theoretically, the Johansen test is based on matrix theory and the theory of its eigenvalue. Let $\mathrm{k}>2$ be the number of nonstationary and integral first order series I (1) included in the model, and $r$ the number of vectors that co integrate with each-other, where $r \in[0 ; \mathrm{k}-1]$, then the co integration hypothesis is: $r \geq 1$ (there is at least one cointegrating pair). Trace test and Max-Eigen values are lower than the critical values and $\mathrm{p}$-values for them are also insignificant which asserts that Vector Error Correction.

Autoregressive and Moving Average Process $\operatorname{ARMA}(p, q)$. A more general model that can capture infinite 
number of lags for AR process is an Autoregressive and Moving Average Process (ARMA). With fewer lags we can model time series, and this might be preferable to AR model when many lags are present such as the case of inflation. We present below ARMA(p,q) model:

$$
\Delta X_{t}=\alpha+\phi_{1} \Delta X_{t-1}+\ldots+\phi_{p} \Delta X_{t-p}+\varepsilon_{t}+\theta_{1} \varepsilon_{t-1}+\ldots+\theta_{q} \varepsilon_{t-q}
$$

Here for modelling time series $X_{t}$ in addition to $A R(p)$ process we added the moving average $\mathrm{MA}(\mathrm{q})$ process for past $q$ lags of the news $\varepsilon_{t}$. The model can be estimated using maximum likelihood and in practice often a parsimonious (simpler) ARMA $(1,1)$ model is selected [16].

\section{EMPIRICAL ANALYSIS AND FINDINGS}

The analysis of this study are based on quarterly frequency of time series from 2008 to 2020.The meaning of the variables in the model and their description as well as the source of information is shown in the following table 2:

TABLE II: MEANING AND DESCRIPTION OF VARIABLES FOR THE LOANS TO PRIVATE SECTOR AND INDIVIDUALS

\begin{tabular}{cc}
\hline Abbreviation & Description of the variable \\
\hline FL & Finance leasing (measured in milion ALL). \\
ML & Medium-term loans (measured in milion ALL). \\
LL & Long-term loans (measured in milion ALL). \\
REL & Real estate loans (measured in milion ALL). \\
\hline
\end{tabular}

Source: Author's summary. Data from Bank of Albania.

Analyzing the stationarity of these time series we have applied the Dickey-Fuller test. The table 3 below shows the unit root test results for each series. The Dickey-Fuller approach is used to apply the unit root tests.

TABLE III: TIME SERIES STATIONARITY TEST

\begin{tabular}{lcccc}
\hline \multicolumn{1}{c}{$\begin{array}{c}\text { ADF-test } \\
\text { Unite root test }\end{array}$} & t-stat. & Prob. & t-stat. & Prob. \\
\cline { 2 - 5 } & & & & \\
Variable FL; I(1) & -0.1852 & 0.9334 & -6.5818 & 0.0000 \\
Intercept & -1.7865 & 0.6964 & -6.1482 & 0.0000 \\
Trend and intercept & 1.3661 & 0.9551 & -6.2447 & 0.0000 \\
None & & & & \\
Variable LL; I(1) & -2.5173 & 0.1175 & -7.3173 & 0.0000 \\
Intercept & -3.5248 & 0.0475 & -7.4345 & 0.0000 \\
Trend and intercept & 3.7320 & 0.9999 & -3.8685 & 0.0002 \\
None & & & & \\
Variable ML; I(1) & -2.3869 & 0.1506 & -4.8951 & 0.0002 \\
Intercept & -1.9926 & 0.5907 & -5.0650 & 0.0008 \\
Trend and intercept & 0.3135 & 0.7723 & -4.8946 & 0.0000 \\
None & & & & \\
Variable REL; I(1) & -3.6099 & 0.0089 & -7.0049 & 0.0000 \\
Intercept & -3.4115 & 0.0613 & -7.1517 & 0.0000 \\
Trend and intercept & 2.0594 & 0.9897 & -6.4559 & 0.0000 \\
None &
\end{tabular}

Source: Data proceeding in EViews 11 by authors. Note: I (1) shows that the series is first-order integral (i.e., it is stationary with first difference)

According to ADF test, all the variables are found out to be non-stationary for level form, however their first difference turns these series into stationary ones. These time series are influenced by the effect of the trend, i.e., they are non-stationary at the level, so, finding their long-term (equilibrium) relationship will be applied the Johansen test. According Johansen approach [19], we have only two possibilities: co integrating relationship or no co integration. This approach suggests two kind of statistical tests: trace test and maximum eigenvalue test. Firstly, we have to determine the optimum lag (time retrospective of the variable). The results of optimum lag are in Table 4 below:

TABLE IV: LAG ORDER OPTIMAL SELECTION CRITERIA

\begin{tabular}{ccccccc}
\hline Lag & LogL & LR & FPE & AIC & SC & HQ \\
\hline 0 & -1873.124 & NA & $5.76 \mathrm{e}+29$ & 79.87761 & 80.03507 & 79.93686 \\
1 & -1658.731 & $383.1705^{*}$ & $1.25 \mathrm{e}+26^{*}$ & $71.43535^{*}$ & $72.22265^{*}$ & $71.73162^{*}$ \\
2 & -1650.416 & 13.44527 & $1.76 \mathrm{e}+26$ & 71.76238 & 73.17951 & 72.29566 \\
3 & -1643.092 & 10.59692 & $2.64 \mathrm{e}+26$ & 72.13156 & 74.17853 & 72.90184 \\
4 & -1630.775 & 15.72308 & $3.34 \mathrm{e}+26$ & 72.28830 & 74.96511 & 73.29561 \\
\hline
\end{tabular}

$*$ indicates lag order selected by the criterion.

LR: sequential modified LR test statistic (each test at $5 \%$ level).

FPE: Final prediction error.

AIC: Akaike information criterion.

SC: Schwarz information criterion

HQ: Hannan-Quinn information criterion.

Source: authors' calculation in Eviews 11.

We have decided to choose the "lag" equal to 4 because the most of criterions suggest it. This lag is the best according to economics meaning (the data are quarter of year). According to optimal criterion we found out lag $=1$. Now we need to identify co integration pairs, and the results are shown in the Table 5 below:

TABLE V: ESTIMATIONS OF CO-INTEGRATION RANK TEST (TRACE) AND RANK TEST (MAXIMUM EIGENVALUE)

\begin{tabular}{ccccc} 
& \multicolumn{2}{c}{ RANK TEST (MAXIMUM EIGENVALUE) } \\
\hline \multirow{2}{*}{$\begin{array}{c}\text { Hypothesized } \\
\text { No. of CE(s) }\end{array}$} & \multicolumn{2}{c}{ Rank Test (Trace) } & \multicolumn{2}{c}{$\begin{array}{c}\text { Rank Test (Maximum } \\
\text { Eigenvalue) }\end{array}$} \\
\cline { 2 - 5 } & $\begin{array}{c}\text { Trace } \\
\text { Statistic }\end{array}$ & Prob. & $\begin{array}{c}\text { Max-Eigen } \\
\text { Statistic }\end{array}$ & Prob. \\
\hline None & 26.48564 & 0.8730 & 14.18466 & 0.8097 \\
At most 1 & 12.30098 & 0.9209 & 7.284480 & 0.9419 \\
At most 2 & 5.016500 & 0.8071 & 4.642954 & 0.7860 \\
At most 3 & 0.373546 & 0.5411 & 0.373546 & 0.5411 \\
\hline
\end{tabular}

Source: authors' calculation in Eviews 11.

We found out that there is no long-run (equilibrium) relationship between these variables. Therefore, the analysis should be done in the relation of the variables with their values in retrospective (autocorrelation). This analysis was performed only for the variable FL, as following:

TABLE VI: AUTOCORRELATION ESTIMATION OF VARIABLE FL

\begin{tabular}{|c|c|c|c|c|c|c|c|c|}
\hline \multicolumn{2}{|c|}{ Autocorrelation } & \multicolumn{3}{|c|}{ Partial Correlation } & $A C$ & PAC & Q-Stat & Prob \\
\hline 1 & & 1 & & 1 & 0.932 & 0.932 & 46.911 & 0.000 \\
\hline I & 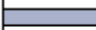 & & 1 & 2 & 0.861 & -0.054 & 87.772 & 0.000 \\
\hline 1 & $\square$ & 1 다 & 1 & 3 & 0.778 & -0.127 & 121.86 & 0.000 \\
\hline 1 & $\square$ & 1 & I & 4 & 0.711 & 0.078 & 150.97 & 0.000 \\
\hline
\end{tabular}

Source: authors' calculation in Eviews 11 .

Table 6 shows that the variable FL has autocorrelation with lag = 1 so there is no equilibrium with $95 \%$ confidence interval. The Ljung-Box joint test statistic rejects the null hypothesis of no autocorrelation at the $1 \%$ level for all numbers of lags considered (in our case lag $=4$ ). It could be concluded that a mixed ARMA process could be appropriate.

According to the empirical analysis for the ARMA model in Albanian Finance Leasing, we identify the relationship for forecasting as shown in the table 6 . In our study is estimates ARMA $(1,1)$ model. At first, the model was analyzed $\operatorname{ARMA}(p, q)$ form for $p=1,2,3,4$ and $q=1,2,3$, 4. According to the minimization criterion "Akaike Information Criterion," the best form is ARMA $(1,1)$ approach, which best fits and forecasting the time series of 
leasing financing (variable FL).

TABLE VII: PARAMETRIC ESTIMATION OF ARMA (1,1) OF DEPENDED VARIABLE "FL"

\begin{tabular}{lcc}
\hline \multicolumn{1}{c}{ Variable } & $\begin{array}{c}\text { Coefficient or model } \\
\text { parameters }\end{array}$ & $\begin{array}{c}\text { Probability of statistical } \\
\text { significance }\end{array}$ \\
\hline C & 101.2036 & $0.0000^{*}$ \\
AR (1) & -0.7281 & $0.0000^{*}$ \\
MA (1) & 1.2589 & $0.0000^{*}$ \\
Adjusted R & 0.3252 & \\
Prob(F-statistic) & 12.5674 & $0.0000^{*}$ \\
Durbin-Watson stat & 1.9752 & \\
Akaike info criterion & 13.3480 & min \\
\hline
\end{tabular}

Note: AR (1) is the first lag of the autocorrelation and MA (1) is the moving average is the first lag of the residual (error term of the model). Also, is noted: *for statistical significance level of $\mathrm{p}<1 \%$.

Source: authors' calculation in Eviews 11.

The general ARMA forecasting equation for the FL variable is ARMA $(1,1)$ :

$$
\Delta F L_{t}=101.20-0.73 \Delta F L_{t-1}+1.26 \varepsilon_{t-1}+\varepsilon_{t}
$$

According to the Fisher test, the model is statistically significant with significance level $\mathrm{p}<1 \%$. The model also has a satisfying determinant coefficient, with an adjusted coefficient of determination $32.52 \%$. Further analyzing the model and its parameters, we have used t-test which estimates statistically significant negative autocorrelations (with significance $\mathrm{p}<1 \%$ ) with lag $=1$, and statistically significant negative moving average (with significance $\mathrm{p}<$ $1 \%$ ) with lag $=1$.

Starting with a financing value of 101.2 million ALL, we see that in the future the value will change with an inverse relationship with a coefficient of 0.73 on each quarterly change of the previous value of the finance leasing. If the change in the finance leasing in the current quarter increases by one million ALL this is expected to affect a decrease in the next quarter by 0.73 million, i.e., starting with the constant 101.2 million ALL plus 1 million ALL (current value of finance leasing) minus 0.73 million ALL (autocorrelation effect with lag $=1$ ) equal to 101.47 million ALL quarterly (short-term) equilibrium of the finance leasing.

On the other hand, the larger the error term the larger will be the volatility of the forecasting values. So, starting with the constant 101.2 million ALL plus 1 million ALL (current value of finance leasing) plus 0.73 million ALL multiplied by coefficient $1.26^{*}$ volatility of the error term (previous estimation). In this case, we pointed the error effect out with more than the autocorrelation effect. This phenomenon shows that has no long-run equilibrium, furthermore, forecasting values in the short-run have a large interval or are harder to forecast. Finance leasing in Albania is a part of the financial sector so difficult to forecast even if we are analyzed data in the short run.

\section{CONCLUSION}

Financing with leasing is a very motivating form of medium-term financing for small and medium enterprises, by creating financing opportunities in fixed assets in production lines, machineries, new technologies, etc.
Leasing contracts are not obligated by collateral or other forms of guarantee, this makes an opportunity for additional investment in business assets. Even though finance leasing is a potential source of financing for enterprises regardless of their business cycle, still businesses in Albania have not used it as an important medium-term loan, because the products offered by leasing entities are only in personal transport and work transport vehicles.

This limitation of the leasing portfolio causes enterprises in Albania a lack of the diversification potential in the average cost of capital, by limiting project application and doing business. The main reason for this undeveloped finance leasing in other products is related to the fact that commercial banks offer such products and have collaborated traditionally with businesses with sustainable performance in their investment capital needs. In these circumstances, it is necessary to have more promotion by the leasing entities themselves, and also the supervisory authorities of the financial market should construct regulation to develop this financial sub-sector as well. Nowadays, around the world, there are many studies that declare finance leasing does not have a direct relationship with the business cycle, so this financing source is potentially usable in every period of development of a business.

This study is based on time series data from 2008 to 2020 with quarterly frequency. By applying the cointegration test and ARMA approach, we found out that there is no cointegration (long-run equilibrium) between finance leasing with variables medium-term loans, long-term loans, and real estate loans. Therefore, econometric tests suggest optimal forecasting $\operatorname{ARMA}(1,1)$ modeling. The parameters of the ARMA model are negative statistically significant with autocorrelation $\mathrm{AR}(1)$ and statistically significant positive with the moving average MA(1), and forecasting values have a short-run equilibrium with a wide interval. According to this short-term equilibrium, a reduction in finance leasing by 1 million ALL in the current quarter will increase by 0.73 million ALL finance leasing in the upcoming quarter. While a positive volatility trend more than the current forecast is expected to give a positive effect in the upcoming quarter of finance leasing.

Taking all statistical analysis, findings, and conclusions into account is very essential that Central Bank, commercial banks, central and local government institutions, leasing entities, financial advisory institutions, and all stakeholders, may consider these findings of this scientific paper for different decision-making such as adding products to the leasing portfolio, more focus on this potential financial subsector, clear development regulations and procedures, etc.

The main limitation of this study derives from the shortcomings of data for the individual leasing entities and funding amounts by sectors of the economy. As consequence, this study did not use the method of finding endogenous and exogenous factors for finance leasing. 


\section{REFERENCES}

[1] Bank of Albania (2008, 2009, ... 2020). Monthly Statistical Report. https://www.bankofalbania.org/Publications/Periodic/Monthly_Statist ical_Report/.

[2] Bank of Albania (2018). Annual Supervision Report. https://www.bankofalbania.org/Publications/Periodic/Supervision_An nual_Report/.

[3] Bank of Albania (2019). Annual Supervision Report. https://www.bankofalbania.org/Publications/Periodic/Supervision_An nual_Report/.

[4] Berger, A. \& Udell, G. (2005). A More Complete Conceptual Framework for Financing of Small \& Medium Enterprises. World Bank Policy Research Working Paper No. 3795.

[5] Bierman, H. (2005). The Lease versus Buy Decision. Englewood Cliffs, NJ: Prentice-Hall.

[5] Boyd, J.H. \& De Nicolo, G. (2004). The theory of bank risk-taking and competition revisited. The Journal of Finance, Vol. 60, No. 3, pp.1329-1343.

[6] Burgress, D.O. (2002). Buy or lease: the eternal question. Journal of Accountancy, 187(4), 2533.

[7] Carey, M. \& Stulz, R. M. (2005). The Risk of Financial Institutions, NBER Working Paper 11442. http://www.nber.org/papers/w1142.

[8] Chemmanur, T., \& Yan, A. (2000). Equilibrium leasing contracts under double-sided asymmetric information. Boston College working paper.

[9] Contino, R. (2004). Negotiating Business Equipment Leases. McGraw-Hill Inc.

[10] Dexter, J., \& Hecimovich, G. (2014). Structuring and Modeling Leasing Investments -Tax Perspectives. Deloitte Tax LLP.

[11] Dickey, D. \& Fuller, W. (1979); "Distribution of the estimations for autoregressive time series with a unit root", Journal of American Statistical Association, 74, 423-31.

[12] Elgers, T. \& Clark, J. (2010). The Lease/Buy Decision: A Simplified Guide to Maximizing Financial and Tax Advantages in the 1980s. New York, NY: The Free Press.

[13] European Commission (2012). Non-bank financial institutions: Assessment of their impact on the stability of the financial system. Economic Papers 472.

[14] Ezzell, J \& Vora, P. (2001). Leasing versus purchasing: Direct evidence on a corporation's motivations for leasing and consequences of leasing. The Quarterly Review of Economics and Finance 41(1), $33-47$.

[15] Gilligan, T. (2004). Lemons and leases in the used business aircraft market. Journal of Political Economy 112, 1157-1180.

[16] Goldman, E. (2020). Lecturer notes: Data Analysis in Finance. Pace University.

[17] Gujarat, D., \& Porter D. (2009); Basic Econometrics (5th ed.). McGraw-Hill.

[18] Hendel, I., \& Lizzeri, A. (2002). The role of leasing under adverse selection. Journal of Political Economy 110, 113-142

[19] Johansen, S., \& Juselius, K. (1990). Maximum likelihood estimation and inference on co-integration-with applications to the demand for money. OXFORD Bulletin of Economics and Statistics 52(2), 169210.

[20] Korbi, A \& Lleshaj, L1. (2015). The Financial Leasing in Albania and its Financing Costs. European Scientific Journal 11(7), 369 - 378.

[21] Ling, D., Naranjo, A., \& Ryngaert, M. (2012). Real Estate Ownership, Leasing Intensity, and Value: Do Stock Returns Reflect a Firm's Real Estate Holdings? The Journal of Real Estate Finance and Economics 44:184-202. DOI 10.1007/s11146-010-9271-2.

[22] Mao, W., \& Zaleski, P. (2011). The Effect of Leasing versus Buying on Entry Deterrence. Managerial and Decision Economics, 32: 325 331. DOI: $10.1002 /$ mde. 1537.

[23] Merton, R.C. (1995). A Functional Perspective of Financial Intermediation. Financial Management, Vol 24(2), pp. 23 - 41.

[24] Merton, R.C. (1993). Operation and Regulation in Financial Intermediation: A Functional Perspective. pp.17-69, Harvard Business School Press, Boston, MA.

[25] Myers, S., \& Majluf, N. (2002). Corporate financing and investment decisions when firms have information that investors do not have. Journal of Financial Economics, 7(2), 187-221.

[26] Noeth, B. J. \& Sengupta, R. (2011). Is Shadow Banking Really Banking?. The Regional Economist, Federal Reserve Bank of St. Louis, pp. 13.

[27] Pozsar, Z \& Singh, M. (2011). The Nonbank-Bank Nexus and the Shadow Banking System. IMF Working Paper WP/11/289.

[28] Stanton, R. \& Wallace, N. (2004), An Empirical Test of a Contingent Claims Lease Valuation Model. Economics, 31(3), 313-315.
[29] Tobias. A. \& Shin, H.S. (2009). The Shadow Banking System: Implications for Financial Regulation. Banque de France Financial Stability Review 13, pp. 1-10.

[30] Westley, G. (2003). Equipment Leasing and Lending: A Guide for Microfinance. Washington, D.C.: Inter-American Development Bank Reference No. MSM-122.

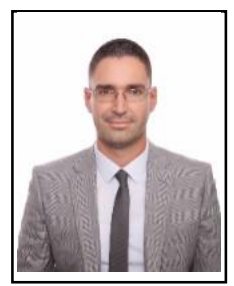

Alban Korbi currently holds the position Vice Dean at the Faculty of Economics, University of Tirana Albania. He is full time lecturer at the Finance Department at the Faculty of Economics, University of Tirana, since 2005. He has received the title "Docent" in 2010, in corporate finance field, and finished Ph.D. studies in 2015. Doctoral thesis: "Financial leasing, an alternative source of financing for Albanian enterprises: Quantitative and qualitative analysis of this source of funding in Albania." He published many professional and scientific papers, and several lesson notes. In addition to scientific research, he lectures in the course of Advanced Financial Management, and International Financial Management; etc; and is an editorial board member in a national scientific journal. Experience in scientific and professional work is the result of his participation in several national strategic projects.

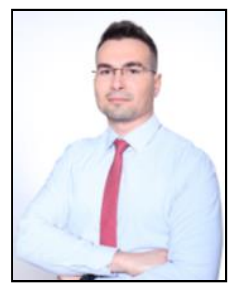

Llesh Lleshaj, Ph.D. in Statistics, is a full-time Lecturer at the Faculty of Economy, University of Tirana, Albania. Doctoral thesis: "Assessment of Foreign Direct Investments and Their Cost of Capital: Case of Albania". He published about 30 professional and scientific papers, and a university book "Introduction to Financial Modeling" and severa lesson notes. In addition to scientific research, he lectures in the course of Econometrics; Applied Business Statistics; Financial Modeling; etc; and is an editorial board member in two international scientific journals, and actively carries out the role of a reviewer. Experience in scientific and professional work is the result of his participation in several national strategic projects and various professional jobs in the industry, like banking and private business. 